\title{
Théologiques
}

\section{La spiritualité dans les organisations}

Une nouvelle approche de la gestion du changement organisationnel?

\section{Christiane Demers et Sherazade Adib}

Volume 9, numéro 2, automne 2001

Sens et spiritualité dans les pratiques professionnelles

URI : https://id.erudit.org/iderudit/007297ar

DOI : https://doi.org/10.7202/007297ar

Aller au sommaire du numéro

Éditeur(s)

Faculté de théologie de l'Université de Montréal

ISSN

1188-7109 (imprimé)

1492-1413 (numérique)

Découvrir la revue

Citer cet article

Demers, C. \& Adib, S. (2001). La spiritualité dans les organisations : une nouvelle approche de la gestion du changement organisationnel ?

Théologiques, 9(2), 95-115. https://doi.org/10.7202/007297ar d'utilisation que vous pouvez consulter en ligne.

https://apropos.erudit.org/fr/usagers/politique-dutilisation/ 


\section{La spiritualité dans les organisations. Une nouvelle approche de la gestion du changement organisationnel ?*}

Christiane Demers et Sherazade ADIB

École des Hautes Études commerciales

Montréal

Depuis quelque temps, le monde de la gestion porte une attention particulière aux questions touchant la spiritualité dans les organisations. En effet, de plus en plus d'articles de la presse populaire, de la presse des affaires ainsi que des sites Web traitent de ce phénomène et font état de livres, de conférences et de cours qui portent sur ce sujet. Particulièrement important aux États-Unis depuis une dizaine d'années avec l'apparition du "mouvement pour la spiritualité au travail », ce phénomène est souvent présenté comme un nouveau paradigme visant à transformer les organisations ${ }^{1}$. Comme nous nous intéressons depuis un certain temps au domaine du changement organisationnel ${ }^{2}$, nous avons voulu comprendre en quoi la spiritualité, dans les organisations, constituait une nouvelle approche au changement dans les organisations.

* Les auteurs souhaitent remercier le FCAR pour son support financier.

1. Voir, entre autres, le double numéro spécial sur la spiritualité dans les organisations, du Journal of Organizational Change Management publié en 1999 (ci-après JOCM).

2. C. DEMERS, «De la gestion du changement à la capacité de changer. L'évolution de la recherche sur le changement organisationnel de 1945 à aujourd'hui ", Revue Gestion, 24 (1999) p. 131-139; idem, "La diffusion d'un changement radical. Un processus de redéfinition et de restructuration de l'organisation ", Communication et organisation. Le changement organisationnel, une perspective communicationnelle, ISIC-Université Michel de Montaigne, 1993, p. 95-127; T. HAFSI et C. DEMERS, « Le changement radical dans les organisations complexes. Des éléments de comparaison et une généralisation ", Le changement radical dans les organisations complexes, Boucherville, Gaëtan Morin Éditeur, 1989, p. 231-277. 
Dans cette étude nous avons analysé des articles tirés des principales revues en gestion ainsi que les ouvrages académiques les plus cités sur le sujet. Notre objectif était d'identifier la définition de la spiritualité utilisée par les auteurs, de mettre au jour la conception du changement organisationnel préconisée et de dégager les principaux courants qui émergent de cette littérature. Suite à cette analyse, nous avons comparé cette approche dite "nouvelle " aux autres perspectives dans le domaine de la gestion du changement organisationnel pour découvrir sa spécificité.

\section{Le contexte de l'étude}

Il faut préciser ici qu'il ne s'agit pas d'une étude exhaustive, mais plutôt de l'exploration d'une thématique qui émerge dans le champ de la gestion. D'après notre recension, la majorité des écrits à ce jour sont soit des articles de la presse des affaires ou de quotidiens comme Business Week, News Week, le Globe and Mail, La Presse et Le Devoir ${ }^{3}$, soit des livres de consultants (du style livre de recettes) et des autobiographies de dirigeants. Or, nous voulions savoir ce que les théoriciens et les chercheurs en gestion disaient sur le sujet. Nous avons donc concentré notre analyse sur les écrits en gestion de nature académique, c'est-à-dire ceux qui ont paru au cours des cinq dernières années dans les revues spécialisées du domaine telles que Academy of Management Review, Academy of Management Journal, Administrative Science Quaterly ou Journal of Management Studies, ainsi que dans les principales revues pour praticiens comme Harvard Business Review, Sloan Management Review et Organizational Dynamics. Nous avons également examiné les livres écrits par des chercheurs qui publient dans ces revues. Il faut souligner que nous avons mis l'accent sur la littérature nord-américaine parce que c'est là que cette thématique a d'abord suscité l'intérêt. Ce que nous présentons est donc une perspective avant tout anglo-saxonne.

3. «Baby Boomers Explore Their Spiritual Coming-of-Age ", Financial Post, 17-19 février, 1996, p. 23; R. DUTRISAC, " Pensée magique et management soft ", Le Devoir, 4 avril 1998 ; " The Growing Presence of Spirituality in Corporate America. Religion in the Workplace ", Business Week, $1^{\text {er }}$ novembre 1999 ; E. CHURCH, "Soul Surfaces in the Office Canyons », The Globe and Mail, 22 mai 1998, p. B21 ; S. WHOTAKER, "Spirituality in the Workplace », The Gazette, 29 août 1998. 
La première constatation que nous avons faite est que le corpus n'est pas très volumineux, environ une vingtaine d'articles et quelques livres, pour la plupart des collectifs. La plupart des écrits à ce jour sont l'œuvre de consultants et de praticiens. Peu d'articles ont été écrits dans les revues spécialisées du domaine de la gestion. En fait, nous n'avons trouvé qu'un seul article traitant de ce sujet, et de façon plus ou moins explicite, dans les revues les plus reconnues (classées A dans le Citation Index) et il s'agissait d'un texte critique.

Les textes que nous avons analysés (outre les ouvrages cités en notes, voir la liste donnée en annexe) peuvent être divisés en deux groupes dont un est très largement dominant, celui du discours prospiritualité et un autre beaucoup plus marginal qui comprend quelques textes plus critiques. Dans les pages qui suivent nous décrirons ces deux discours sur la spiritualité dans les organisations.

\section{Le discours pro-spiritualité}

Il se caractérise par un ensemble d'écrits qui sont essentiellement normatifs et prescriptibles. Ces textes utilisent en guise d'illustrations et d'exemples les cas anecdotiques de quelques entreprises, souvent les mêmes. La majorité de ces textes ne développent pas de cadre conceptuel. Il y a cependant quelques efforts isolés de classification, de comparaison de concepts et de théorisation ${ }^{4}$. On constate également l'absence d'études empiriques rigoureuses du phénomène de la spiritualité dans les organisations, l'exception étant la recherche menée par Mitroff ${ }^{5}$ sur laquelle nous reviendrons plus tard.

À la première lecture, ce qui ressort, en plus des références qui sont très semblables d'un texte à l'autre et des mêmes exemples qui

4. T. C. PaUCHANT, «Pour une éthique spirituelle du travail. Quelques inspirations de Simone Weil ", dans T.C. PAUCHANT, dir., Pour un management éthique et spirituel. Défis, cas, outils et questions. Les actes du colloque, Montréal, Fides et Presses HEC, 2000, p. 148-164 ; I.I. MitrofF, " La spiritualité au travail. Le prochain défi majeur en management ", dans PaUCHANT, Pour un management éthique et spirituel, p. 48-57; G.F. CAVANAGH, "Spirituality of Managers. Context and Critique ", JOCM, 12/3 (1999) p. 186-191; B. FRESHMAN, « An exploratory Analysis of Definitions and Applications of Spirituality in the Workplace », JOCM, 12/4 (1999) p. 318-327. 5. MitrofF, "La spiritualité au travail ». 
reviennent, c'est la ressemblance dans les arguments, notamment en ce qui a trait aux raisons derrière l'apparition de la spiritualité dans les organisations, aux particularités de l'organisation spirituelle, ainsi qu'aux caractéristiques du processus de transformation des entreprises vers ce qui est décrit comme un nouveau paradigme. À ce plan, les propos des auteurs se rapprochent beaucoup. C'est pourquoi nous allons d'abord discuter de ce qui est commun à l'ensemble de ces textes, avant de comparer les différentes variantes de ce discours qu'un examen plus approfondi permet de découvrir.

\subsection{Pourquoi la spiritualité dans les organisations?}

La première constante dans le discours pro-spiritualité est la réflexion sur les raisons qui motivent l'intégration de la spiritualité dans les organisations. La plupart des auteurs font état du sentiment d'appartenance à une communauté et de la quête de sens chez les individus dans notre société. Par exemple, Konz et Ryan affirment en se référant à Miller :

People are searching for meaning in work that transcends mere economic exchanges between isolated, autonomous individuals. People are searching for a way to connect their work lives with their spiritual lives, to work together in community, to be unified in a vision and purpose that goes far beyond making money ${ }^{6}$.

Ce besoin de sens est exprimé par un nombre grandissant de personnes qui travaillent dans des organisations à travers le monde. Cette quête de sens est ressentie par des employés, des gestionnaires, des cadres, des cadres supérieurs, des dirigeants, des consultants, des professeurs ou des étudiants. Ce besoin est générique à la condition humaine en général et il est particulièrement ressenti aujourd'hui dans le monde du travail ${ }^{7}$.

Les auteurs notent également l'importance de plus en plus grande des organisations dans la vie des gens. Dans un monde où les lieux traditionnels d'identification, comme la famille, l'Église et le voisinage ne remplissent plus le rôle de support moral et psychologique, le monde du travail devient prédominant. C'est au travail que les gens passent

6. G.N.P. KONZ et F.X. RYAN, "Maintaining an Organizational Spirituality. No Easy Task ", JOCM, 12/3 (1999) p. 200.

7. T.C. PAUCHANT, "Le management éthique et spirituel répond à un besoin de sens au travail ", dans PAUCHANT, Pour un management éthique et spirituel, p. 10-36 (ici p. 11). 
le plus de temps, c'est là qu'ils ont le plus d'occasions de se réaliser. Comme le souligne Conger :

For many of us, the workplace has become our primary source of community. It is where we spend the majority of our time. It is where many of our friendships and relationships take place. It is where we seek a good deal of our challenges in life. It is where we contribute to our society ${ }^{8}$.

Or, le constat qui est fait par ces auteurs est que les organisations sont actuellement génératrices de stress pour les individus. Biberman et Whitty affirment :

Large systems and organizational processes have been undermined through cultural pathologies, addiction and shadow. This is the modern paradigm - toxic stress and inequity in the name of profit ${ }^{9}$.

Biberman et Whitty ajoutent "Toxic stress, selfish competitiveness and inequity in the name of profit have created an economic and organizational world out of balance. ". De même, Pauchant dit à ce propos : "Des effets négatifs de ce manque de sens sont aussi divers et inquiétants: augmentation du stress, de l'épuisement professionnel et des troubles psychiques $[\ldots]^{10} »$.

Ainsi, la course à la compétitivité ferait en sorte qu'on en demande toujours plus aux employés et que ceux-ci se sentent insécurisés ou souffrent de "burn-out ». Pour changer cette situation préoccupante, les auteurs suggèrent que les organisations doivent se transformer en intégrant des valeurs spirituelles, ce qui leur permettrait de devenir génératrices de sens. Biberman et Whitty, par exemple, justifient ainsi le paradigme spirituel :

Working people and human evolution itself are constantly seeking meaning, purpose and a sense of contribution to work life. These needs are best served and deepened when a spiritual paradigm frames the intentions of all stakeholders ${ }^{11}$.

8. J.A. CONGER, "Introduction. Our Search for Spiritual Community », dans J.A. CONGER, dir., Spirit at Work, Calif., Jossey-Bass Publishers, 1994 (ici p. 1).

9. J. Biberman, M. WhitTY et L. RobBins, «Lessons from OZ. Balance and Wholeness in Organizations ", JOCM, 12/3 (1999) p. 243-254.

10. PAUCHANT, « Le management éthique et spirituel ", p. 12.

11. Biberman, WhitTY et Robbins, «Lessons from OZ », p. 170. 
Les organisations ainsi transformées permettraient à leurs employés de se réaliser et pourraient ainsi profiter de leur engagement et de leur motivation, comme le souligne Tischler :

Workers and managers alike are becoming more like independent brokers of their services and knowledge, and are not only looking for money but increasingly for other values such as meaning, personal and professional growth, and even spiritual growth ${ }^{12}$.

Mais que deviendraient ces organisations transformées que certains appellent organisations spirituelles?

\subsection{Organisation traditionnelle et organisation spirituelle: \\ une opposition}

C'est là que l'on retrouve la deuxième ressemblance majeure dans cette littérature, l'organisation spirituelle y est définie comme l'opposée de l'entreprise traditionnelle. Cette opposition s'articule autour de ce qui est défini comme la vision fragmentée propre à l'approche traditionnelle et la vision holiste caractéristique du nouveau paradigme.

L'organisation traditionnelle y est présentée comme une entité avant tout économique et rationnelle, alors que l'organisation spirituelle y est définie comme privilégiant les valeurs non-économiques et rejetant la pensée rationnelle occidentale. Selon Waddock, les problèmes de fragmentation de l'organisation traditionnelle seraient dûs en bonne partie à ce mode de pensée rationnel :

Part of the answer lies in the "Cartesian split (Overton, 1998) that characterizes much of western thought. This split has brought us the distinction between mind or spirit and body, between the ineffable and what Westerners perceive as the "real » or, alternatively, between the subjective and the objective, the material and the immaterial ${ }^{13}$.

Les auteurs discutent ainsi d'une série de dichotomies, notamment entre objectif et subjectif, matériel et spirituel, public et privé auxquelles l'approche rationnelle a donné naissance. Ils distinguent l'organi-

12. L. TISCHLER, "The Growing Interest in Spirituality in Business. Alongterm Socio-economic Explanation », JOCM, 12/4 (1999) p. 273-279 (ici p. 273).

13. S.A.WADDOCK, "Linking Community and Spirit. A Commentary and Some Propositions ", JOCM, 12/4 (1999) p. 332-344 (ici p. 335). 
sation traditionnelle qui favorise l'objectif et le matériel au détriment du subjectif et du spirituel, de l'organisation spirituelle qui favorise l'intégration. Ils regrettent que la séparation entre privé et public nuise au développement d'organisations où la coopération et le sens de communauté règnent :

We have made rigid demarcations between our private and public lives, reserving the spiritual for the private realm and leadership for our professional and public lives. This separation has created psychological and emotional blinders that rob those in management and leadership positions of view of the whole ${ }^{14}$.

Le paradigme de l'organisation spirituelle qu'ils mettent de l'avant est axé sur la collaboration plutôt que sur la compétition et sur l'apprentissage plutôt que sur le contrôle. Pour leur part, Neal, Bergmann Lichtenstein et Banner, discutent comment le nouveau paradigme remet en cause le modèle de gestion de l'entreprise traditionnelle:

[...] management thoughts have been dominated by the assumption that the job of the manager is to control everything, so that things turn out right, i.e., according to plan (Mintzberg, 1994) [...] the new management paradigm is suggesting alternatives to this notion of command and control [...] a new model of experiment, service, self-organize, and learn (Hench, 1998) ${ }^{15}$.

Pauchant va dans le même sens en affirmant:

Ces logiques restrictives - ces fragmentations du réel - incluent le rationalisme technocratique abusif présent dans de nombreuses organisations; la suprématie de « l'économisme» dans les décisions stratégiques et managériales qui, calculant le coût de chaque chose, ne connaît plus leur valeur; ou l'importance des politicailleries de couloir qui orientent certaines des activités des entreprises au seul profit d'un petit nombre de personnes ${ }^{16}$.

Finalement, ce nouveau paradigme redéfinit la relation individuorganisation. On passe d'une vision où l'individu est au service de l'organisation et doit être contrôlé, à une vision de l'organisation où

14. K.T. SCOTT, «Leadership and Spirituality. A Quest for Reconciliation ", dans CONGER, Spirit at Work, p. $63-99$ (ici p. 67).

15. J.A. Neal, M. BergmanN Lischtenstein et D. BANNER, "Spiritual Perspectives on Individual, Organizational and Societal Transformation ", JOCM, 12/3 (1999) p. 175-185 (ici p. 181-182).

16. PAUCHANT, "Le management éthique et spirituel ", p. 12. 
le bien-être de l'individu et celui de l'organisation sont indissociables. Une question qui se pose alors est: comment passe-t-on de l'approche traditionnelle à l'approche spirituelle ? Comme nous le verrons dans la prochaine section, sur ce sujet aussi, les propos des auteurs se rapprochent beaucoup.

\subsection{Le processus de transformation}

Les textes en général mettent en évidence deux niveaux de changement qui forment une séquence. Dans un premier temps, une étape de conversion individuelle où le manager prend conscience de ses besoins spirituels et poursuit une démarche personnelle pour intégrer la spiritualité dans sa vie professionnelle. La deuxième étape débute quand le manager entreprend la transformation de son organisation en agissant comme leader auprès de ses employés.

Scott, par exemple, met l'accent sur la capacité du leader à gérer sa démarche personnelle:

The capacity to move into the void is directly related to leaders' capacity to deal with their own internal polarities. [...] this integration [of the inner and outer world] is greatly influenced by the internal struggle in the psyche for balance ${ }^{17}$.

Neal, Bergmann Lichtenstein et Banner, pour leur part, soulignent l'importance de la conversion individuelle comme pré-requis au changement organisationnel :

Individual transformation is needed because managers and leaders must be proactive leaders, open to change, and flexible enough to adapt to constantly shifting demands from their organizations ${ }^{18}$.

En effet, cette première étape est essentielle puisque c'est aux managers que revient le rôle de guide dans cette démarche de transformation spirituelle de l'organisation. Ainsi, selon Konz et Ryan :

The spirituality of the leaders is the key to maintaining the organization's spirituality. The leader's spirituality should guide what they do, so through their actions, they bring their spirituality to life ${ }^{19}$.

17. SCOTT, « Leadership and Spirituality ", p. 69.

18. Neal, Bergmann Lischtenstein et BANNER , "Spiritual Pespectives on Individual», p. 175.

19. KONZ et RYAN, «Maintaining an Organizational Spirituality », p. 203. 
Comme on peut le constater, la vision du changement qui émerge de ce discours est celle d'un changement intentionnel planifié par la direction pour les employés. Les managers sont investis du rôle d'agent de changement. Leurs valeurs spirituelles inspirent ce changement qui se fait dans le but de créer un sens d'appartenance à une communauté où tous sont solidaires et participent au bien commun : " The importance of creating a sense of community that inspires individual commitment to a set of goals encompassing the common as well as the individual $\operatorname{good}^{20} »$.

\subsection{Les variantes $d u$ discours pro-spiritualité en gestion}

Au-delà des ces grandes similarités, une analyse plus systématique des textes fait toutefois ressortir certaines différences intéressantes. Ces différences apparaissent lorsque l'on s'intéresse de façon plus approfondie au sens qui est donné à la spiritualité dans les textes. Ainsi, on observe que le concept de spiritualité s'exprime en termes d'un continuum dont un des pôles est le religieux et l'autre, le séculier. On peut regrouper les textes selon trois positions le long de ce continuum que nous avons appelé les variantes religieuse, spirituelle et culturelle/ morale (voir en annexe le tableau 3). Il est important ici de préciser que ce ne sont pas des catégories étanches, mais plus des variations sur un thème ${ }^{21}$. Dans les paragraphes qui suivent, nous allons brièvement présenter chacune de ces variantes ou courants à travers les dimensions suivantes (voir en annexe tableau 1) : les définitions et motsclés, les conséquences pour la gestion, notamment le rôle du gestionnaire, les pratiques individuelles et/ou collectives qui sont préconisées. Ensuite nous discuterons des fondements conceptuels de chacun de ces courants.

La variante religieuse, comme son nom l'indique, regroupe les textes où l'auteur donne une place importante à la religion dans sa définition de la spiritualité et en discute l'influence sur les pratiques de certaines organisations. La majorité de ces textes font surtout réfé-

20. WADDOCK, "Linking Community and Spirit », p. 333.

21. D'ailleurs il est intéressant de noter que la typologie des organisations que Mitroff a construite suite à son étude sur la spiritualité dans les organisations possède des catégories très semblables à celles-ci. 
rence à la tradition chrétienne. L'extrait du texte de Cavanagh est un bon exemple de cette variante du discours pro-spiritualité:

Spirituality enables a businessperson to gain a better perspective on their firm, family, neighbours, community and themselves. Furthermore acknowledging dependence on God gives the individual manager a more stable and helpful vision [...]

Business schools in religiously-oriented universities are thus challenged to take a leadership role in helping all universities to integrate spirituality, religion and religious values into their education ${ }^{22}$.

Nous avons remarqué qu'une bonne partie des auteurs de ce courant enseignent dans des universités catholiques aux États-Unis où le mouvement "spirituality in business " est très important. Quelquesuns des auteurs sont membres de communautés religieuses. Ce discours met Dieu à l'avant-scène et souligne l'importance de la foi dans la vie au travail. La famille et les valeurs familiales y sont également très présentes. Par exemple, McDermott le présente ainsi :

Partnering with God, finding one's deepest identity in one's relationship with God, and developing a sense of God's longing to act in and with groups can help a person in the role of authority stay in the fray for the long haul ${ }^{23}$.

Le gestionnaire dont il est ici question est un croyant pratiquant pour qui la foi est une source d'inspiration tant dans la vie professionnelle que personnelle. Une éthique de service est également mise en évidence tant en ce qui concerne le rôle des dirigeants face à leurs employés qu'en ce qui regarde les rapports aux clients. Du point de vue des pratiques concrètes, la contemplation, la prière et le travail communautaire sont celles qui reviennent le plus souvent : "Executives, workers, and often the companies they are with, attempt to bring quiet, wholeness, spirit and even contemplation and prayer into their $\operatorname{lives}^{24} »$.

22. CAVAnagh, "Spirituality of Managers ", p. 198.

23. B.O. McDermotT, s.j., " Partnering with God. Ignatian Spirituality and Leadership in Groups », dans CONGER, Spirit at Work, p. 132-161, (ici p. 159).

24. CaVAnaGH, «Spirituality of Managers », p. 194. 
Toutefois, ce courant n'est pas le plus important, c'est la variante spirituelle qui domine de loin la littérature actuelle. Ce second courant regroupe des textes où l'on fait attention de distinguer religion et spiritualité, en insistant sur le fait que cette dernière est beaucoup plus englobante. Ce discours précise que l'on peut être spirituel sans adhérer à une religion et souligne l'importance d'avoir une vision intégratrice lorsqu'il s'agit d'introduire la spiritualité dans les organisations. Ce courant qui est généralement basé sur une vision individuelle de la spiritualité met l'accent sur la transcendance. Cet extrait de Burack exprime bien l'esprit de ce courant :

[...] the following concepts of spirituality in the workplace will be used: Spiritual growth and advancement of the human experience involve mental growth $[\ldots]$

Spiritual growth reflects the gratification of individual needs especially "belonging" and those of a higher order such as a sense of achievement. The individual's context for these is broad, encompassing work-family connections and work-place settings.

Spirituality in the work place is communicated and reinforced through the institution's leaders, organizational culture, policies and work design among other factors. Sensitivity to and interest in the person (employee) must be common to all approaches ${ }^{25}$.

Selon cette variante, les gestionnaires sont conçus comme des guides spirituels qui permettent aux employés de poursuivre une démarche de croissance personnelle:

Managers now are seen as guides who help create meaning and purpose for their subordinates [...] As the concern for finding meaning in work became greater, managers moved into the role as aids to the search for meaning in the workplace ${ }^{26}$.

Certains suggèrent l'intégration de pratiques de croissance personnelle, tandis que d'autres proposent la modification des pratiques de gestion existantes. Pauchant, par exemple, met l'accent sur l'intégration de nouvelles pratiques:

[...] ce niveau trans-personnel doit aussi contribuer à de nouvelles pratiques dans les organisations, non directement accessibles à partir des autres niveaux. [...]

25. E.H. BURACK, "Spirituality in the Workplace ", JOCM 12/4 (1999) p. 280-291 (ici p. 280-281).

26. KONZ et RYAN, " Maintaining an Organizational Spirituality », p. 200. 
L'utilisation du silence, de l'intuition, de la méditation, de la contemplation ou de la prière dans les processus de décision ${ }^{27}$.

Konz et Ryan voient les pratiques liées au recrutement et à la socialisation des employés comme source majeure d'influence dans la gestion des organisations:

The leaders spirituality also influences the selection of employees[...] The organization would seek out those individuals whose spiritualities match the organization's spirituality[...] The spirituality of the organization's leaders maintains the spirituality of the organization through its influence on the socialization of new employees ${ }^{28}$.

Ce courant est fréquemment associé au Nouvel Âge (Harvard Business Review; Cavanagh); des auteurs comme Pauchant mettent en garde contre l'attitude égocentrique que l'on reproche souvent à ce mouvement.

Le troisième courant, le plus séculier, celui que nous avons appelé $l a$ variante culturelle, associe la spiritualité au partage de grandes valeurs universelles. Comme le mentionnent Milliman et ses collègues :

One of the challenging aspect of spirituality is that it seems to mean different things to different people, making it difficult to give a universal definition of this dynamic concept. Nonetheless, in all cases it appears to involve deeply-held values ${ }^{29}$.

Certains auteurs précisent que ces valeurs sont communes à toutes les grandes traditions philosophiques et religieuses. Ce courant qui est plus exclusivement ancré dans le domaine de la gestion est très proche de la littérature sur la culture organisationnelle des années ' $80^{30}$. Par

27. Pauchant, "Le Management éthique et spirituel », p. 31-32.

28. KONZ et RYAN, "Maintaining an Organizational Spirituality », p. 203204.

29. J. Milliman, J. Ferguson, D. Trickett et B. Condemi, « Spirit and Community at Southwest Airlines. An Investigation of a Spiritual Valuesbased Model ", JOCM, 12/3 (1999) p. 221-233 (ici p. 221).

30. T. DeAl et A. KenNEDY, Corporate Culture, Addison-Wesley, 1982 ; W. OUCHI et A. WILKINS, "Organizational Culture ", Annual Review of Sociology, 11 (1985) p. 457-483 ; T.J. PETERS et R.H. WATERMAN, In Search of Excellence. Lessons from America's Best-run Companies, New York, Harper and Row, 1982. 
exemple, des auteurs comme Wagner-Marsh et Conley associent valeurs morales et succès des entreprises.

[...] certain basic attitudes and practices that appear to be essential for success in maintaining a spiritually-based corporate culture. [...] honesty with self $[. .$.$] mutual trust and honesty with others, commitment to qua-$ lity and service, commitment to employees $[\ldots]^{31}$.

Selon cette variante, le gestionnaire doit être un modèle de conduite pour les employés : "Leadership and the organization demonstrated concern for employees, respect for others, consistency of actions and demonstrated acumen ${ }^{32}$ ". Les pratiques qui sont mises de l'avant visent à s'assurer l'engagement des employés. Notamment, on cite en exemple les pratiques suivantes de SouthWestern Airlines (SWA) :

SWA asks a lot of its employees and in return provides them with a wide range of financial and non-financial rewards. [...] They offer profit sharing, bonus, retirement saving policies, and stock option plans ${ }^{33}$.

Il est intéressant de noter ici que ce sont souvent les mêmes exemples d'entreprises qui reviennent dans les trois variantes. Plusieurs de ces cas sont ceux d'entreprises qui ne s'identifient pas elles-mêmes, comme des entreprises "spirituelles ", par exemple SWA ou Ford, mais que les auteurs définissent comme telles en fonction de leur définition de ce qu'est la spiritualité dans les organisations. On constate donc que les exemples concrets restent peu nombreux et qu'il y a une grande convergence dans la façon dont la spiritualité s'exprime dans les pratiques concrètes quelle que soit la définition de la spiritualité que l'on adopte.

Quand on s'intéresse au cadre conceptuel ou aux fondements qui sous-tendent ces trois courants, on remarque d'abord que tous font référence à la psychologie notamment à l'école des relations humaines dont l'un des pionniers, Abraham Maslow (1954), qui a développé la pyramide des besoins (des plus primaires liés à la survie physique aux plus élevés, les besoins d'actualisation), est presque toujours men-

31. F. Wagner-Marsh et J. CONLEY, "The Fourth Wave. The spirituallybased Firm ", JOCM, 12/4 (1999) p. 280-291 (ici p. 291).

32. BURACK, "Spirituality in the Workplace ", p. 285.

33. Milliman et al., "Spirit and community at Southwest Airlines", p. 228. 
tionné. Cependant, dans la variante religieuse, on fait aussi référence à des théologiens, comme Teilhard de Chardin, et à des figures religieuses comme saint Ignace de Loyola. Dans la variante spirituelle, la psychologie domine très fortement. Particulièrement, la psychologie humaniste qui a inspiré l'école des relations humaines; mais on fait également de nombreuses références à la psychologie transpersonnelle et à Ken Wilber. Enfin, dans le dernier courant, celui des valeurs et de la culture, ce sont les auteurs en gestion, qui traitent notamment de culture organisationnelle et d'éthique d'affaires, qui sont les plus cités.

Pour conclure, ce qui émerge du discours pro-spiritualité, c'est d'abord la croyance en la transcendance, c'est-à-dire la croyance en l'existence d'un ordre ou d'une force supérieure qui donne un sens à la vie. Un deuxième élément important, c'est l'accent sur l'expérience de l'individu que ce soit celle de la foi en Dieu, de la conscience transpersonnelle ou de la responsabilité morale et de l'identification à la communauté. Finalement, un autre élément qui ressort du discours pro-spiritualité c'est l'importance qu'il accorde au dirigeant et aux gestionnaires. À cet égard, il est d'ailleurs intéressant de noter que la seule étude empirique faite sur le sujet de la spiritualité dans les organisations par Mitroff s'est intéressée aux perceptions des dirigeants et des cadres ${ }^{34}$. À ce jour, il n'y a pas eu, à notre connaissance, d'études systématiques sur les opinions des employés sur cette question.

\section{Le discours critique}

Comme nous le soulignions plus tôt, l'essentiel des écrits sur le sujet de la spiritualité en gestion fait la promotion de ses avantages pour les organisations. Ou bien on est pro-spiritualité, ou bien on n'en parle pas, du moins jusqu'à présent. Il y a cependant quelques exceptions. Trois textes analytiques qui ont une vision plus critique, traitent, de façon plus ou moins directe, de ce sujet. Toutefois, aucun d'entre eux ne se base sur une recherche empirique systématique ou une analyse exhaustive de la littérature récente sur la spiritualité dans les organisations.

Selon ces auteurs, la spiritualité dans les organisations n'est qu'un pas de plus dans le développement de méthodes plus efficaces de

34. MitrofF, «La spiritualité au travail ». 
contrôle des individus. Ackers et Preston, par exemple, soutiennent que cette approche met la responsabilité du changement organisationnel sur l'individu :

There are numerous examples of a new confessional idiom in business that conjugates change with cohesion. [...] Yet one more, which mirrors directly evangelical Christianity, is the focus on the cultural realm as the fount of spiritual power and empowerment and as a mechanism for changing the world by transforming the individual heart and $\operatorname{mind}^{35}$.

À leurs yeux, le discours sur la spiritualité est une idéologie qui soustend un ordre normatif. O'Reilly et Chatman, qui analysent les similarités des pratiques entre les organisations " à culture forte ", les religions et les sectes, définissent ainsi la culture :

In our view, culture can be thought of as the normative order, operating through informational and social influence, that guides and constrains the behaviour of people in collectives. [...] we define culture as a system of shared values (that define what is important) and norms that define appropriate attitudes and behaviours for organizational members (how to feel and behave) ${ }^{36}$.

Or, leur conception de la culture est très proche de certaines définitions de la spiritualité du discours pro-spiritualité. Ils utilisent d'ailleurs les mêmes exemples que ces auteurs. D'après eux, c'est par les intentions des dirigeants et l'intensité des pratiques que l'on peut distinguer les organisations "à culture forte" ou organisations "spirituelles» des mouvements religieux ou des sectes - les intentions et l'intensité - les mécanismes de contrôle étant les mêmes.

To develop the strategically appropriate normative order, three general steps are taken by almost all strong culture organizations; (1) promoting commitment through participation by designing processes such as rigorous selection and orientation processes and job designs that require multiple steps ; (2) managing the informational context through managing signalling, often symbolically, that certain goals, attitudes, and

35. P. ACKERS et D. PRESTON, « Born Again ? The Ethics and Efficacy of the Conversion Experience in Contemporary Management Development ", Journal of Management Studies, 34/5 (1997) p. 677-701.

36. C.A.O. O'Reilly et J.A. Chatman, "Culture as a Social Control. Corporations, Cults and Commitment ", Research in Organizational Behaviour, 18 (1996) p. 160. 
behaviour are important [...]; (3) developing comprehensive reward systems that aligned with the culture and that provide rapid feedback, an emphasis on appropriate attitudes and behaviour, and continuous recognition ${ }^{37}$.

Comme on le constate, les pratiques de gestion qui sont décrites se rapprochent beaucoup de celles qui sont préconisées dans le discours pro-spiritualité ; elles mettent l'accent sur le renforcement psychologique plutôt que matériel. Dans cette perspective, le dirigeant devient un agent de contrôle social et la spiritualité est un moyen plus sophistiqué pour imposer un contrôle subtil, non coercitif.

[...] a new management rhetoric has emerged that turns its back on the appeals of legal-rational authority, and entreats employees in a language redolent of charismatic authority and evangelical religion ${ }^{38}$.

Par l'utilisation de l'action symbolique et la gestion du discours, on favorise un engagement encore plus total des employés qui doivent se convertir pour appartenir au groupe. Ackers et Preston sont particulièrement critiques face à ces expériences de conversion qui, selon eux, sont souvent forcées :

[...] the majority of religious conversions are based on a freely chosen voluntary commitment that infuses the whole of the person's life with new meaning [...]. By contrast, MD [Management Development] conversion rests, in large part, on involuntary and temporary compliance to an organization, and thus raises ethical questions about the rights of those employees who participate ${ }^{39}$.

Ce discours critique est basé sur une conception politique des organisations et une vision plus conflictuelle et moins optimiste que les tenants du discours pro-spiritualité. On met l'accent sur le fait que le pouvoir est asymétrique dans les organisations et que les dirigeants peuvent se servir de la spiritualité comme d'un outil de domination. À titre de synthèse, voir en annexe le tableau 2.

37. O'Reilly et Chatman, " Culture as a Social Control », p. 175.

38. ACKERS et PRESTON, "Born Again ? ", p. 684.

39. ACKERS et PRESTON, "Born Again ?", p. 679. 


\section{Discussion}

Dans les pages qui suivent, nous présentons quelques questions et commentaires que suggère ce bref tour d'horizon. Nous avions commencé cette étude en nous posant la question suivante : la spiritualité dans les organisations est-elle une nouvelle approche à la gestion du changement?

Nous avons vu que plusieurs auteurs qui font la promotion de la spiritualité dans les organisations la présentent comme un nouveau paradigme, alors que les auteurs plus critiques n'y voient qu'une nouvelle étiquette. À leurs yeux, il ne s'agit que d'une sophistication accrue des mécanismes de contrôle social dans les organisations. Nous répondons à cette question en disant oui et non. L'analyse systématique des textes de ces auteurs révèle que cette approche est une combinaison de l'école des relations humaines (de laquelle a émergé le courant du développement organisationnel) et du courant culturel qui a fortement influencé la gestion durant les années ' 80 . Toutefois, cette approche a une caractéristique importante qui la différencie des précédentes, c'est l'accent sur la transcendance. En ce sens, elle est encore plus englobante que les précédentes et elle accentue la pression qui est faite sur l'individu pour s'identifier totalement à l'organisation.

Sur la thématique du changement qui est le point de départ de cette étude, un autre élément qui ressort de notre analyse est la vision du changement qui est présentée dans la majorité des textes et que nous qualifions de "management spirituel ». La transformation des organisations par l'intégration de la spiritualité y est décrite comme une intervention délibérée des dirigeants. Il s'agit pour l'essentiel d'une vision managériale où la direction est le principal agent de changement. C'est le gestionnaire qui a la responsabilité de guider les employés dans leur démarche spirituelle.

Cette observation nous suggère le commentaire suivant: le phénomène de la spiritualité dans les organisations peut également être conçu en termes d'une vision plus décentralisée du changement. C’est ce que nous qualifions de "spiritualité au travail " qui correspond à un mouvement émergent, spontané, plutôt qu'à une intervention organisée. Il ne s'agit pas ici d'un processus dirigé par les gestionnaires mais d'une dynamique d'auto-organisation dont les employés intéressés prennent en charge le développement. Dans un tel contexte, la par- 
ticipation est réellement volontaire et l'intégrité personnelle est respectée; si les gestionnaires sont impliqués, ils réagissent aux initiatives des employés.

\section{Conclusion}

En conclusion, cette étude exploratoire soulève au moins deux préoccupations :

- Quelle place veut-on laisser aux organisations dans nos vies ?

- Quelles responsabilités et quels droits les organisations ont-elles face à leurs employés, face à la société ?

Une des justifications pour l'intégration de la spiritualité dans les organisations est le fait que les organisations occupent déjà une place très importante dans nos vies et qu'elles remplacent progressivement la famille et la communauté comme lieu d'identification. Les questions qui se posent alors sont :

- Veut-on leur laisser toute la place?

- Est-ce là la solution ?

- Les objectifs d'une organisation et de ses dirigeants peuvent-ils être entièrement compatibles avec ceux des employés ?

Ceci nous amène à notre deuxième préoccupation: quelles sont les responsabilités et les droits des organisations ? Certains auteurs qui prônent l'intégration de la spiritualité dans les organisations prétendent que, compte tenu de leur place prépondérante dans nos sociétés, les organisations ont la responsabilité de donner du sens à nos vies. Ils se basent pour dire cela sur des études qui montrent que les individus ressentent un vide dans leur existence et souhaitent intégrer davantage la spiritualité dans leur vie. Un tel raisonnement qui donne aux gestionnaires la responsabilité du bien-être spirituel de leurs employés, leur donne également le droit de s'immiscer dans leur vie. Cependant, il faudrait peut-être demander aux employés ce qu'ils en pensent. Ce n'est pas parce qu'ils donnent leur temps et leur énergie à l'organisation qu'ils souhaitent nécessairement qu'elle prenne la responsabilité de leur âme. 


\section{ANNEXES}

T A B LE A U 1

Classification des textes en gestion de la spiritualité

\begin{tabular}{|c|c|c|c|}
\hline & Versant religieux & Versant spirituel & Valeurs \\
\hline Descriptif & $\begin{array}{l}* \text { F. Cavanagh } \\
* \text { Dion } \\
* \text { R. Berthouzoz }\end{array}$ & $\begin{array}{l}* \text { T. Pauchant } \\
* \text { I. Mittroff }\end{array}$ & * Elmer H. Burack \\
\hline Normatif & $\begin{array}{l}* \text { F. Cavanagh } \\
* \text { Brian O. } \\
\text { McDermott } \\
* \text { John C. Haughey }\end{array}$ & $\begin{aligned} & \text { Sandra King et } \\
& \text { Dave M. Nicol } \\
* & \text { Jerry Biberman et } \\
& \text { Michael Whitty } \\
* & \text { Gregory N.P Konz } \\
& \text { et Francis X. Ryan } \\
* & \text { T. Pauchant } \\
* & \text { I. Mittroff } \\
* & \text { Parker J. Palmer } \\
* & \text { Katherine Tyler Scott } \\
* & \text { D. Susan Wisely et } \\
& \text { Elizabeth M. Lynn }\end{aligned}$ & $\begin{array}{l}\text { * Elmer H. Burack } \\
* \text { John Milliman, } \\
\text { * Jeffrey Ferguson, } \\
\text { David Trickett et } \\
\text { Bruce Condemi } \\
\text { S. J. Porter, } \\
\text { J. Mc Call et } \\
\text { T. A. Bausch } \\
\text { * Fraya Wagner Marsh } \\
\text { et James Conley } \\
\text { * Mark P. Kriger et } \\
\text { Bruce J. Hanson } \\
\text { * Rabindra } \\
\text { N. Kanungo et } \\
\text { Manuel Mendonça }\end{array}$ \\
\hline
\end{tabular}

TABLEA 2

\section{Discours critique en gestion}

\begin{tabular}{|l|l|}
\hline Définition & Ordre normatif \\
\hline $\begin{array}{l}\text { Implications pour la } \\
\text { gestion }\end{array}$ & $\begin{array}{l}\text { Le gestionnaire comme agent de contrôle social } \\
\text { S'assurer de l'engagement des individus } \\
\text { Utilisation de l'action symbolique et la gestion de sens }\end{array}$ \\
\hline Mécanismes/pratiques & $\begin{array}{l}\text { Programmes de développement managérial = } \\
\text { expérience de conversion religieuse } \\
\text { Sélection des employés (contrat explicite) } \\
\text { Système de récompense qui met l'accent sur les bonnes } \\
\text { attitudes à adopter }\end{array}$ \\
\hline Entreprises & $\begin{array}{l}\text { Fast Feet, } \\
\text { Hewlett-Packard, } \\
\text { SWA, } \\
\text { Nordstrom }\end{array}$ \\
\hline
\end{tabular}


T A B LEA U 3

Discours pro-spiritualité en gestion

\begin{tabular}{|c|c|c|c|c|}
\hline & Religion & \multicolumn{2}{|c|}{ Spiritualité } & Culture/valeurs \\
\hline $\begin{array}{l}\text { Définitions/ } \\
\text { mots-clés }\end{array}$ & $\begin{array}{l}\text { Dieu } \\
\text { Famille } \\
\text { Foi }\end{array}$ & \multicolumn{2}{|c|}{$\begin{array}{l}\text { Transcendance } \\
\text { Développement } \\
\text { individuel } \\
\text { Conscience }\end{array}$} & $\begin{array}{l}\text { Honnêteté } \\
\text { Dignité humaine } \\
\text { Confiance } \\
\text { Responsabilité }\end{array}$ \\
\hline $\begin{array}{l}\text { Implications } \\
\text { pour la gestion }\end{array}$ & $\begin{array}{l}\text { Gestionnaires } \\
\text { pratiquants } \\
\text { Gestion axée } \\
\text { sur le service }\end{array}$ & \multicolumn{2}{|c|}{$\begin{array}{l}\text { Gestionnaires-guides } \\
\text { spirituels } \\
\text { Encourager le dével- } \\
\text { oppement spirituel }\end{array}$} & $\begin{array}{l}\text { Gestionnaires- modèles } \\
\text { de conduite éthique } \\
\text { Favoriser l'engagement } \\
\text { des employés }\end{array}$ \\
\hline $\begin{array}{l}\text { Mécanismes/ } \\
\text { Pratiques } \\
\text { (individuel ou } \\
\text { collectif) }\end{array}$ & $\begin{array}{l}\text { Prière } \\
\text { Contemplation } \\
\text { Travail commu- } \\
\text { nautaire / } \\
\text { bénévolat }\end{array}$ & \multicolumn{2}{|c|}{$\begin{array}{l}\text { Programmes } \\
\text { psychospirituels : } \\
\text { la méditation } \\
\text { La croissance } \\
\text { personnelle } \\
\text { Sélection } \\
\text { et socialisation des } \\
\text { employés } \\
\text { Travail d'équipe }\end{array}$} & $\begin{array}{l}\text { Sélection des employés } \\
\text { Système de mentorat } \\
\text { Système de récompenses } \\
\text { financières et } \\
\text { non-financières } \\
\text { Travail d'équipe }\end{array}$ \\
\hline Exemples cités & \multicolumn{2}{|c|}{ Entreprises } & & Leaders \\
\hline & \multicolumn{2}{|c|}{$\begin{array}{l}\text { Boeing, AT\&T, Ford, Semco, } \\
\text { Lotus Developpement, } \\
\text { Landcaster, Mary Kay Cos- } \\
\text { metics, SWA, Tom's Of } \\
\text { Maine, Hewlett-Packard }\end{array}$} & \multicolumn{2}{|c|}{$\begin{array}{l}\text { Vaclav Havel } \\
\text { Mère Térésa } \\
\text { Mahatma Gandhi }\end{array}$} \\
\hline
\end{tabular}

\section{Autres textes analysés non cités}

Bolman, L. G. et E. DeAL, Leading with Soul, an Uncommon Journey of Spirit, San Francisco, Jossey-Bass Publishers, 1995.

CONGER, J.A., "Conclusion: Reuning Spirituality and Work », dans J.A. CONGER, dir., Spirit at Work, Calif., Jossey- Bass Publishers, 1994, p. 199-213.

DiOn, M., "Éthique des affaires et spiritualité chez les juifs, les chrétiens et les musulmans ", dans dans T.C. PAUCHANT, dir., Pour un management éthique et spirituel. Défis, cas, outils et questions. Les actes du colloque, Montréal, Fides et Presses HEC, 2000, p. 175-182.

, "Les entrepreneurs chrétiens au Québec», dans C. MÉNARD et F. VILlENEUVE, dir., Spiritualité contemporaine. Défis culturels et 
théologiques, Actes du congrès 1995 de la société canadienne de théologie, Montréal, Fides, 1996.

FreshmAN, B., « An Exploratory Analysis of Definitions and Applications of Spirituality in the Workplace, JOCM, 12/4 (1999), p. 318-327.

HAUGHEY J.C., "A Leader's Conscience: The Integrity and Spirituality of Vaclav Havel », dans CONGER, Spirit at Work, p. 41-62.

HAwKINS, P., "The Spiritual Dimension Of Learning Organization", Management Education and Development, 22/3 (1991) p. 172-187.

KANUNGO, R.N. et M. MENDONÇA, "What Leaders Cannot do Withhout: The Spiritual Dimensions of Leadership ", dans CONGER, Spirit at Work, p. 162-198.

KING, S. et D. M. NICOL: "Organizational Enhancement Through Recognition of Individual Spirituality. Reflexion of Jacques and Jung ", JOCM, 12/3 (1999) p. 234-242.

Krieger, M. et B. HANson, "A Value-based Paradigm for Creating Truly Healthy Organizations ", JOCM, 12/4 (1999) p. 302-317.

Mc Whinney, W., Paths Of Change, Calif., Sage Publications, 1997.

Michols, M., "Does New-Age Business Enterprise Trust Awards", Harvard Business Review, mars-avril (1994) p. 52-60.

O’Toole, J., « Do Good , Do Well: The Business Enterprise Trust Awards », California Business Review, avril (1994) p. 9-22.

PALMER, P.J., "Leading from Within: Out of the Shadows, into the Light ", dans CONGER, Spirit at Work, p. 19-40.

PORTH, S. J. et J. MCCALL, "Spiritual Themes of the Learning Organization ", JOCM, 12/3 (1999) p. 211-220.

WISELY, D.S. et E.M. LYNN, "Spirited Connections: Learning to Tap the Spiritual Resources in Our Lives and Work ", Spirit At Work, p. 100131. 